\title{
Tourism and cosmopolitanism: a view from below
}

\author{
Noel B. Salazar \\ Cultural Mobilities Research, \\ Faculty of Social Sciences, \\ University of Leuven, \\ Parkstraat 45, bus 3615, \\ BE-3000 Leuven, Belgium \\ Fax: +32-16-325902 \\ E-mail: noel.salazar@soc.kuleuven.be
}

\begin{abstract}
Based on long-term fieldwork in Indonesia and Tanzania, this article sheds new light on the contested relationship between tourism and cosmopolitanism. The ethnographic findings shift the attention from tourists to key service providers as those accruing most cosmopolitan capital through the tourism encounter. Local tour guides are able to use their privileged contacts with foreign visitors to develop cross-cultural competencies and to enhance their own cosmopolitan status. They substantiate the idea that cosmopolitanism is no privilege of the rich and well-connected and that physical or spatial mobility is not a necessary condition to become cosmopolitan. Paradoxically, the guides' dreams of becoming more cosmopolitan (and more modern and Western) can only materialise if they represent to tourists their lifeworld, including themselves, as frozen in both time and space, because it is exactly this kind of imaged and imagined difference tourism sells to tourists for the build-up of their own cosmopolitan capital.
\end{abstract}

Keywords: socio-cultural anthropology; ethnographic fieldwork; tourism; guiding; local tour guides; tourists; cosmopolitanism; cosmopolitan capital; mobility; imaginaries; Indonesia; Tanzania.

Reference to this paper should be made as follows: Salazar, N.B. (2010) 'Tourism and cosmopolitanism: a view from below', Int. J. Tourism Anthropology, Vol. 1, No. 1, pp.55-69.

Biographical notes: Noel B. Salazar received his $\mathrm{PhD}$ from the University of Pennsylvania (USA). He is currently a Postdoctoral Fellow at the University of Leuven (Belgium) and a Visiting Research Associate at Leeds Metropolitan University (UK). His research interests include anthropologies of mobility, the local-to-global nexus, discourses and imaginaries of otherness, cultural brokering and cosmopolitanism. He has published widely and is the author of Envisioning Eden: Mobilising Imaginaries in Tourism and Beyond (Berghahn Books, Oxford, 2010). He is on the Editorial Boards of Annals of Tourism Research, Mondes du Tourisme and European Journal of Tourism and Hospitality Research. More information is available online at http://kuleuven. academica.edu/NoelBSalazar/. 


\title{
1 Introduction
}

\begin{abstract}
"Tourism is potentially both a cosmopolitan-making and a worldmaking industry. It is global in scope, both universalizing and particularistic, with political economy, cultural and ethical dimensions. As such, it deserves serious analysis, although there had been little general work on these intersections of tourism with cosmopolitanism beyond brief excursions until recently." [Swain, (2009), p.507]
\end{abstract}

Derived from the ancient Greek words kosmos (universe) and polis (city), a cosmopolitan literally means a global citizen. The term can be traced back to the fourth century BCE, when non-Athenian intellectuals began to use it to refer to an imagined community of intellectuals beyond the confines of their Greek city-state. Scholars across the social sciences and humanities have been captivated by the concept of cosmopolitanism (Beck and Sznaider, 2006), variously viewing or invoking it as:

1 a socio-cultural condition

2 a kind of philosophy or world view

3 a political project toward building transnational institutions

4 a political project for recognising multiple identities

5 an attitudinal or dispositional orientation

6 a mode of practice or competence [Vertovec and Cohen, (2002), pp.8-14].

I am particularly interested in the latter two perspectives, the more cultural and experiential ones (cf. Hannerz, 2004) because they allow for an ethnographic focus on the way people perform and enact cosmopolitanisms in their everyday lives.

Cosmopolitanism is a dynamic between universalisms and diversity, constructed in encounters between people. But how does one become a cosmopolitan? How to accrue and display this 'stance in the management of cultural experience' [Hannerz, (2004), p.71]? First, 'the perspective of the cosmopolitan must entail relationships to a plurality of cultures', including 'an orientation, a willingness to engage with the other' [Hannerz, (1990), p.239]. This necessitates a flexible intellectual and aesthetic openness toward divergent cultural experiences, a search for contrasts rather than uniformity - the allure of elsewhere and otherness. Cosmopolitanism requires not only tolerance, respect and enjoyment of cultural difference, but also a concomitant sense of global belonging, a kind of growing global consciousness that can be integrated into everyday life practices [Tomlinson, (1999), p.185] - a difficult task given that the world is structured by considerable inequality. It is widely believed that such a cosmopolitan outlook or disposition - a desirable contemporary form of cultural capital - is largely acquired through experience, especially transnational travel (Notar, 2008). Anthropologists have argued that travel is a fundamental aspect of cosmopolitanism, either mentioning it directly (Clifford, 1997) or by describing the mobility that enables travel experiences (Ong, 1999). Travel-for-leisure or tourism around the globe could thus be seen as a prime example of cosmopolitanism-as-practice, allowing people to accumulate knowledge about 'other' worlds (Hannerz, 1990, 2004; Urry, 1995).

If global tourism marketing suggests tight links between boundary-crossing travels and cosmopolitanism, how (if at all) is this connection achieved in practice? Of course, only 'some tourists seek out the particular qualities of a distant place ... rather than 
embracing it as a whole; others want the distant place to be as much like home as possible' [Hannerz, (2004), p.74]. While the (dis)connection between tourism and cosmopolitanism has been addressed elsewhere with regard to tourists (Molz, 2005; Swain, 2009), in this paper, I look at the issue from below, by focusing on tourism service providers. I explore the narrative strategies and performative techniques local guides use to turn tours into cosmopolitan-enhancing experiences, in rather unexpected ways. Tour guides have to ensure their clients are delivered exactly the kind of experiences they expect, the images and fantasies travel agencies or tour operators sold to them when they booked their trip. How exactly do guides realise the travel dreams of tourists, skilfully mediating the gap between expectations and actual experience? How do they link sites with what tourists expect from them, integrating visited people and places into broader tourism imaginaries, and rendering them continuous with their imagined context? And what does this tell us about the presupposed links between tourism and cosmopolitanism?

I approach this set of questions by way of a multi-sited micro-ethnographic analysis, looking at two very different types of tourism encounter, namely cultural tourism in central Java's Yogyakarta (Indonesia) and safari tourism around East Africa's 'safari capital', Arusha (Tanzania). I carried out fieldwork over a period of 25 months, 14 months of which I was in Indonesia (July-August 2003, January-December 2006) and 11 months in Tanzania (June-August 2004, January-August 2007). A major part of the research consisted of extensive observation. As a participant, I joined tourists (XE 'tourist') on 28 tours in central Java and 24 trips in northern Tanzania (XE 'Tanzania:northern'). As an observer, I spent countless hours socialising with local tour guides and informally talking to them. These different types of observation led to hundreds of pages of field notes. The second most important source of data is interviews. I conducted and recorded in-depth interviews with guides $(26,30)$ and semi-structured interviews with people involved in guide training $(6,7)$, local tour operators $(5,15)$ and tourism authorities at local, national and regional levels $(11,13)$. The numbers in between brackets indicate how many people I interviewed in Indonesia and Tanzania respectively. My local assistants carried out additional short, structured street interviews with locals $(35,23)$. In Indonesia, I gathered supplementary data from tourists (XE 'tourist') through a short questionnaire on tour guiding; in Tanzania, I obtained the same information talking to tourists during safaris.

\section{Imaging otherness through a cross-cultural lens}

Because they contribute considerably to the perception and experience of a destination, local guides are often entrusted with the public relations mission to 'encapsulate the essence of place' [Pond, (1993), p.vii] and to be a window onto the site, city, region, or even country or continent. This ambassadorial role is based on the assumption that there exists a genius loci, a static and unchanging 'spirit' emanating from a place or from the people living there. The qualifier 'local' does not necessarily imply that tour guides are natives of the place where they operate (although they are habitually perceived as such by foreign tourists). In the case of Yogyakarta and Arusha, many were born and raised in the area, but some have roots in other parts of the country. Oftentimes, they migrated to the two respective cities to study or look for a job and settled. In order to fulfil their 
representational duty, professional guides have a wide array of strategies and techniques at their disposal (Salazar, 2010). For instance, they rely on cross-cultural interpretation frames to translate the perceived strangeness of their own culture into an idiom familiar to the foreign clients, finding connections between what is being experienced and what visitors (are assumed to) already know. This helps tourists find 'the familiar in an unfamiliar place' [Notar, (2008), p.616]. Using ethnographic examples from both Indonesia and Tanzania, I will illustrate how this is achieved.

The special Province of Yogyakarta in Indonesia gives tourists access to central Java's rich cultural heritage, including the Sultan's Palace and the nearby World Heritage Sites of Borobudur and Prambanan. Provincial authorities and entrepreneurs use the catchphrase 'Jogja, Never Ending Asia' to attract international tourists to the region. Javanese guides tell visitors mesmerising stories about the beauty and ingenuity of an ancient Asian civilisation, in its distance from the tumultuous present (Salazar, 2005). Pak Padmo (pseudonym), a seasoned guide at the Sultan's Palace, is among the most cosmopolitan guides I met. On a French-spoken tour around the heritage site with a young Swiss couple, he shows off his cross-cultural communication skills and cosmopolitan knowledge. At the entrance of the palace complex, Pak Padmo makes the following comments about a passing group of servants of the Sultan:

"They are like the Scots, men wearing skirts... They wear a dagger, called keris
[Javanese]. The keris is not used as a weapon; it's not only for the guardians of
the palace. It's for those who have served over ten years, as a promotional gift
and symbol of loyalty, like a Rolex... All the servants are barefoot. That's not
good when it's really hot. They become TGV's à la Javanaise... They don't
retire. Even if they are old, they work; but, no problem, in general they do the
RATP. Do you know RATP? It's Reste Assis, T' es Photographié [French;
remain seated, you are being photographed]."

Although Pak Padmo is outspokenly Javanese and has never been outside Indonesia, the fragment above indicates his wide cosmopolitan knowledge. Using simile and metaphor, he repeatedly compares traditional Javanese culture with cultural elements French-speaking tourists easily recognise. This technique is frequently used in tourism to mollify the effects of strangeness associated with a trip abroad [Dann, (1996), pp.171-174]. Moreover, Pak Padmo skilfully selects his information to match the assumed cultural baggage of his Swiss clients. Rolex, for example, is a globally distributed Swiss brand of luxury wristwatches that is widely recognised as a status symbol. TGV is a French acronym for Train à Grande Vitesse, France's well-known high speed rail service. Of course, this strategy of cross-cultural comparisons only works if the tourists share the same frame of reference. In this case, the Swiss woman has to explain to her husband that the RATP acronym of the guide's pun actually stands for Régie Autonome des Transports Parisiens, the major transit operator responsible for public transportation in Paris and its environs.

When passing by the music pavilion of the palace, Pak Padmo gives an entertaining explanation about the traditional gamelan music ensembles:

"Have you already heard gamelan music? It's not like rap! ... Gamelan has nothing to do with the word gamelle [French; lunch box]. Gamelles are like this [taking a small bowl gong and holding it upside down]... Nowadays, they [the court musicians] also play Western instruments because it's not possible to play La Marseillaise [national anthem of France] on gamelan [tourists laughing]." 
While standing in front of the Sultan's residence, Pak Padmo remarks: 'the doors are closed, indicating he's not in the palace... like the flag'. With such cryptic comments, the guide is testing whether his European clients possess as much cosmopolitan knowledge as he does. In this case, he has barely finished his phrase when the female tourist starts laughing loudly and says triumphantly 'Buckingham Palace!', indicating she knows Pak Padmo is alluding to the official flag of the reigning British monarch, only flying over Buckingham when the sovereign is in residence at the palace.

Inside the palace museum, Pak Padmo shows his clients a huge painting depicting a Sultan's coronation:

\begin{abstract}
"He has big pointed ears [indicating the metallic decorations covering the ears of the Sultan]. This has nothing to do with $M r$. Spock... In order to elect a new Sultan, there is a big meeting with wise men, around forty people in total. They meditate and wait for God's answer... It's like a conclave in the Vatican."
\end{abstract}

In another museum room, he gives a brief explanation about Javanese shadow puppet theatre: 'This is Garuda [major shadow puppet character]. It's like Superman in the USA. He flies everywhere to do good deeds. Before the Americans had Superman, the Javanese already had Garuda... Superman is like an adaptation of Garuda'. The references to Spock (the humanoid character in the Star Trek television series, recognisable by his abnormal ears) and Superman indicate that Pak Padmo assumes these figures belong to global popular culture and, thus, should be known by everybody - certainly by well-travelled European tourists. It is interesting to note that the origins of Garuda, the eagle-like king of birds, go back to India, a detail the guide consciously leaves out of his narrative. In any case, it should come as no surprise that pun-loving Padmo is the Palace's French language guide in highest demand. In the fragments above, he gives evidence of a deep knowledge of French language and culture in particular and global popular culture in general.

Some additional examples from a guided tour around the Prambanan temple complex further illustrate the common use of references to global (popular) culture. Pak Supriyadi, a senior on-site guide, is explaining the wall reliefs depicting the age-old Ramayana epic to a group of French tourists: 'Lakshmana [Rama's brother] takes his Swiss knife, ouch no, his Javanese knife, called keris, to make a magic circle to protect Sita [Rama's wife]. Rama and Lakshmana leave for the forest, Sita stays alone in the magic circle ... to be continued next week! [tourists laughing]'. After the light-hearted comparison between the relatively unknown Javanese dagger and the globally renowned Swiss army knife, Pak Supriyadi starts mimicking the genre of a soap opera: briefly summarising the latest developments in the story and stopping the narration at a dramatic moment. He uses the time needed to walk to the second temple, where the depicted story on the wall reliefs continues, to promote the nightly performance at next door's Ramayana Ballet Open Theatre (local advertising time), making the interdiscursive comparison even more striking.

Pak Supriyadi introduces Hanuman, the king of ape-like humanoids, into the Ramayana story and confides that Hanuman consoled Rama with the now famous words: 'Don't worry, be happy!' This humorous piece of narrative immediately struck my attention because it is uttered during a French language tour and involves code switching (French to English). The guide quickly adds the French translation ("ne vous inquietez pas'), but it is obvious that he is referring to the legendary Bobby McFerrin song that is widely used in films, advertising and popular culture. A little later, while pointing to a 
particular geometric pattern on a wall relief panel, Pak Supriyadi clarifies: 'a mandala, but don't be confused with Mandela'. This may be a nice pun, but it is somewhat out of context and outdated - by 2006 (when this tour took place), South Africa's former President Nelson Mandela had greatly retreated from public life due to his age and health issues. The comment should rather be seen as the guide trying to show off his cosmopolitan knowledge. This whole guided tour is a prime example of intertextual narrative performance. Pak Supriyadi, formerly a Ramayana ballet dancer, not only narrates but also enacts (in a very dance-like fashion) parts of the Ramayana story, changing voice pitch when talking about different characters. In addition, he imitates the chants of a Brahman priest while explaining the Hindu rituals taking place in the temple complex.

At the Buddhist shrine of Borobudur, local guides try equally hard to use cross-cultural frames of reference. However, their lack of experience and insufficient training makes this a challenging task. While walking a mixed tour group of Englishspeaking visitors to the main shrine, Pak Marwoto explains the history of the site: 'after a volcanic eruption, the temple was not used and totally abandoned for almost 1,000 years. Exactly like what happened to a small city nearby Rome, Pompeii'. Pompeii was indeed a Roman City, but actually located close to Naples, not Rome. Inside the sanctuary, Pak Marwoto narrates the life of Siddhartha Gautama:

\begin{abstract}
"The history of the life of Siddhartha, of Buddha, is represented in Borobudur in 120 relief panels. It equals the description of Siddhartha's life by a German author, Herman Hesse. The essence of the story is the same... It's a bit similar to the history of Christ. A few days after his birth, he was visited by kings as well... Buddhists call it the golden Buddha because gold is stainless. The soul is pure, uncontaminated, and free from stress and distress. Like the Catholics, you have the Immaculate Conception of the Virgin Mary."
\end{abstract}

It is interesting to note that Pak Marwoto, who like the majority of local guides is Muslim, has not only studied the history of Buddhism, but also seems familiar with elements of Christianity, creating shared frames of religious reference with the predominant Euro-American clientele (cf. Feldman, 2007). He wrongly assumes, however, that all Western tourists are Catholic, while the European visitors on this particular tour were mostly atheists.

On the stroll to the exit gate, Pak Marwoto engages in small talk with the Belgian tourists in the group: 'what is Belgium's best-known beer? [Tourists answer: Stella Artois]. Mhm, internationally known hé, like Heineken, Corona, San Miguel, Felsenschloss, like Paulaner, like Bintang!' The name of the German beer he is trying to recall is not Felsenschloss but Schloss Fels. This fragment gives us some insights as to how chitchat during a guided tour gives an opportunity to build knowledge about other cultures and places. Every time the guide meets clients from another beer-drinking country, he can expand his list. Pak Marwoto also jokingly adds Bintang, Indonesia's bestselling brand of beer (brewed by an Indonesian subsidiary of Heineken). In general, the Indonesian tour guide narratives seem a confirmation of Brennan's (2001, pp.51-52) observation that 'the imbalance of historical learning means that citizens of Indonesia ... know much more about Europe than Europeans generally know about Indonesia'. The acquaintance with the cultural history of the tourists' societies enables guides to focus on aspects of their own culture and traditions that are particularly different, while at the same time lessening the strangeness by using targeted transcultural comparisons and references, sometimes to the surprise of the tourists. 
The guides in Tanzania could learn a great deal from their Indonesian counterparts. Most of them are at work in the booming wildlife tourism business in the northern region. Arusha is the tourist gateway to nearby national parks (Serengeti, Lake Manyara, Tarangire, Arusha and Mt. Kilimanjaro) as well as the celebrated Ngorongoro Conservation Area. The town strategically markets the (colonial) imaginary that, being situated halfway between Cairo and Cape Town, it is 'the centre of Africa'. Local guides benefit from the continuing hype surrounding so-called ecotourism, interpreting their natural and cultural heritage in terms of an untouched, wild Eden, where animals and people live in harmony (Salazar, 2006). They use similar framing strategies like their Indonesian colleagues, but less frequently and not always in the appropriate context.

On a safari to the celebrated Serengeti National Park, driver-guide Samweli tells his US tourists: 'so the Serengeti itself, the National Park, is 14,763 square kilometres, almost the size of Ireland'. To his clients, the size of Ireland, expressed in kilometres, means little to nothing (and the actual size of the island of Ireland is 84,430 square kilometres or 32,600 square miles, comparable to the State of Indiana). While passing by the archaeological site of Oldupai Gorge, Samweli gives some background information about the human species that was found:

\footnotetext{
"It belongs to the same species as the skeleton nicknamed Lucy, which was found in Ethiopia in 1974. But the name Lucy, which is a joke name for that skeleton, was given because during that day the scientists were listening and dancing to the Beatles' song Lucy in the sky with diamonds."
}

This is an entertaining anecdote, but slightly off-topic because it is not about the archaeological findings at Oldupai Gorge itself. There are many nice tales to be told about the discovery of hominid fossils in Tanzania. Most likely, Samweli lacks access to the resources that contain them (even though some of the stories are illustrated in the small museum at the site). This type of limitation prevents guides from creating shared frames of reference. During a visit to a Maasai settlement, for instance, a group of Maasai warriors was dancing and singing with deep-throated voices. One of the tourists remarked that the singing men looked like they were participating in a competition to become the new Tom Waits. Accompanying cultural tourism guide Joseph did not know how to react because he did not know that Tom Waits is an US singer-songwriter famous for his rasped voice.

\section{Imagining the world 'out there'}

The process of becoming expert users of cross-cultural frames of reference brings guides a step closer to becoming cosmopolitans themselves: open to the world and its many facets, roaming the global web of interpretations and expressions, and recognising subtle differences vital to the construction of different identities. Not many local guides in Indonesia or Tanzania have had the opportunity to travel abroad. Nonetheless, through their contacts with former clients and their acquired knowledge of tourists, they have gained an understanding of the societies and cultures these people come from. This cosmopolitan comprehension is vital to their work and resembles that of stereotypical cosmopolites, experienced travellers. In other words, guides do not physically need to wander around the world to develop a cosmopolitan attitude; the world simply comes to 
them. This confirms that 'sheer mobility (in and of itself) does not automatically entail cosmopolitanism' [Swain, (2009), p.513].

Many successful local guides can thus be conceived of as prototype cosmopolites. Of course, not all of them necessarily have cosmopolitan aspirations. Furthermore, not all guide settings and professional roles are equally conducive to enacting cosmopolitan values. But for many guides, the tourism encounter is the liminal setting par excellence in which they can build up their cosmopolitan capital. Paradoxically, contemporary global tourism is structured in such a way that tourists seem to lose out in the quest for cosmopolitan status. Scholars such as Hannerz $(1990,2004)$ equally do not consider tourists to be cosmopolitans due to their perceived lack of interest or competence in participating or translating difference. While this analysis probably fits the majority of tourists, there is a relatively small group intentionally seeking out cosmopolitanenhancing experiences (variously labelled as alternative, eco-, pro-poor tourism, etc.). The kinds of tourists I came across in central Java or northern Tanzania, for instance, were willing to engage with 'the other', but tourism intermediaries (including guides) as well as language barriers make access and dialogue extremely difficult. Guides present tourists, nota bene their best teachers in cosmopolitanism, with imagined and staged versions of local culture - mirrors of widely circulating tourism stereotypes (Salazar, 2010).

If guiding for foreigners can be seen as a cosmopolitan practice, it comes close to anthropology (Kuper, 1994). Kahn (2003, p.411) describes how all ethnographic knowledge is 'inevitably cosmopolitan knowledge; that is a construction that emerges out of the encounter between representatives of different cultures'. Such cosmopolitan competence is marked by 'a personal ability to make one's way into other cultures, through listening, looking, intuiting and reflecting' as well as by 'a skill in manoeuvring more or less expertly with a particular system of meanings and meaningful forms' [Hannerz, (1990), p.239]. Ethnographers undoubtedly recognise in this description elements defining the ideal fieldworker, but, as this article shows, such a description also applies well to professional guides (and, perhaps, to the ideal tour guide). Whereas anthropologists need local informants to construct anthropological knowledge, tour guides cannot do without tourists to jointly (re)create tourism imaginaries and build up cosmopolitan knowledge.

In his earlier writings on the subject, Hannerz (1990) positions White, middle-class and male cosmopolitans and indigenous, native locals as oppositional in the imaginary field demarcated by the global and the local. While the former group appears mobile, contemporary and (post)modern, the latter seems rooted, timeless and traditional. This tacit acceptance of the conventional and stereotype-laden distinction between geographically and socially immobile locals and ever-mobile cosmopolitans has been heavily criticised (Friedman, 1997; Werbner, 2008), as it echoes the earlier disciplinary dichotomy, whereby '"natives' are incarcerated in bounded geo-graphical spaces, immobile and untouched yet paradoxically available to the mobile outsider' [Narayan, (1993), p.676]. Instead, scholars have proposed pluralised and particularised accounts of non-elite 'discrepant cosmopolitanisms' (Clifford, 1997) or 'actually existing cosmopolitanisms' (Malcomson, 1998) that are geographically grounded, historically and socio-economically situated, and embedded in material everyday practices (Breckenridge et al., 2002). In more recent work, Hannerz (2004) is much more nuanced, but still expresses pessimism about the cosmopolitan potential of non-elites, arguing that 'bottom-up' cosmopolitans are unlikely to be recognised as such in their own 
environment. My findings on local tour guides seem to contradict this opinion (see also Notar, 2008; Swain, 2001).

Appadurai (1996, p.57), acknowledging 'the transformation of natives into cosmopolites of their own sort', observes that 'today's cosmopolitanisms combine experience of various media with various forms of experience - cinema, video, restaurants, spectator sports and tourism, to name just a few - that have different national and transnational genealogies' [Appadurai, (1996), p.64]. In a similar vein, Abu-Lughod (1997) argues that cosmopolitanism is not only sought after by those who travel or those who feel at home in several parts of the world, but also by those who stay at home. Her work shows that one not only becomes cosmopolitan through travel and direct contact, but through exposure to the rapid circulation of global signs and images (e.g., television). In other words, mobility alone is neither a sufficient nor a necessary condition for cosmopolitanism.

It is no coincidence Clifford (1997, p.36) includes guides in his list of people 'whose cosmopolitan mobility has been overlooked by narrowly defined elitist forms of cosmopolitanism'. Of course, the cosmobility of guides in developing countries such as Indonesia and Tanzania has to be taken in a figurative sense, as most do not have the means to travel abroad. Nevertheless, their profile includes cross-cultural identifications and aspirations and an interest in cultural difference. Through personal contacts with tourists, other foreigners and the mass media, they can build up their knowledge of foreign experiences, ways of life and social conditions. The cultural capital accumulated from their knowledge of foreigners and foreign countries is a constitutive part of their identity (cf. Favero, 2003). As an added bonus, this cosmopolitan capital also gives them a broader perspective on their own culture, which, in turn, makes them better guides.

Bhabha (1994, p.4) argues that to understand cultural difference is to understand liminal space, the spaces in-between the designations of identity, 'the connective tissues that constructs the difference' between people of different ethnicities and cultures. People able to do this:

\begin{abstract}
"Are the people who belong to more than one world, speak more than one language (literally and metaphorically), inhabit more than one identity, have more than one home; who have learned to negotiate and translate between cultures, and who, because they are irrevocably the product of several interlocking histories and cultures, have learned to live with, and indeed to speak from, difference. They speak from the 'in-between' of different cultures, always unsettling the assumptions of one culture from the perspective of another, and thus finding ways of being both the same as and at the same time different from the others among whom they live." [Hall, (1995), p.206]
\end{abstract}

The description above fits most of the professional guides I met in Yogyakarta and Arusha remarkably well, in the sense that this is exactly the role or social persona they enact. Their understanding of the cultural experiences of strangers is more than what they have been told or read about the stereotypical, inauthentic experiences of cultural outsiders (and, working in tourism, they know exactly what the inauthentic is all about).

The ability to make cosmopolitan connections gives guides a comparative advantage over those who are less familiar with foreign frames of reference. They do not need to travel abroad to experience otherness (although most would love to if they had the financial means): others are coming to them, giving them plenty of opportunity to actively consume cultural differences in a reflective, intellectualising manner. In other 
words, guides do not need physical mobility to become cosmopolitan. This goes against the common assumption that cosmopolitanism arises out of location (metropolitan coastal areas), travel and consumption (Notar, 2008). Like Notar's (2008, p.642) ethnic minority café owners in borderland China, the guides I studied have developed cosmopolitan competences ' $n o t$ in making their way into other cultures and countries, but in catering to those who make their way to them' and their cosmopolitanism 'has arisen not out of travel, consumption or metropolitan residence, but out of producing cosmopolitanism for transnational travellers, and increasingly, national tourists' [Notar, (2008), p.615]. This production of cosmopolitanism has become their means for mobility, not necessarily spatial but both social and transcultural.

However, knowing perfectly well that in many developing countries the guide, as much as the sights seen, are part of the attraction, successful guides have to project themselves into 'local' roles (Salazar, 2005, 2006). This makes them complicit in the perpetuation of biased global tourism imaginaries as well as in the construction of (re)created identities and traditions (Salazar, 2010). While on the discursive level, local guides are (re)producing the kind of (stereotypical) images they are expected to (re)produce, on the metadiscursive level, though, they seem to be conveying a surprisingly dissonant message. There are many instances during guided tours where shifts of role alignment occur and the common asymmetry between guides and tourists is blurred or temporarily interrupted. Two different logics are at work simultaneously: a provincial logic of differentiation that creates differences and divisions, and a cosmopolitan logic of equivalence that subverts existing differences and divisions.

In some instances, guides find creative ways to align themselves on the 'us-tourist' side of the us-them binary, by distancing themselves from the local people encountered during a trip. For example, the dominant global discourse, that would tend to treat all Africans as alike and the Tanzanian guides in Arusha as full members of local communities, can be subverted. This is often achieved through the subtle use of demonstrative and personal pronouns or temporal and spatial expressions. Briefing tourists on the way to Usa River Village, for example, city guide Silva explains: 'we will be able to meet the local people at the market place. You can say habari, so you can become popular suddenly, and they can respect you because you greet them in their language'. Silva performatively resists stereotyping by not telling his clients he is very much a 'local', often frequenting the market they are about to visit to buy his groceries. Noticing how his European tourists enjoy the Maasai singing and dancing, cultural tourism guide Iddi comments: 'I don't know how they do it!' Iddi is actually half Maasai (from his mother's side), but prefers not to be identified as such.

In a bid to enhance their cosmopolitan status, guides in both Tanzania and Indonesia prefer to position themselves as different from the represented locals and more similar to their clients (Salazar, 2007). Such practices have been noticed elsewhere as well:

"Bumsters on the beach in The Gambia buy into the myth of global citizenship through the discourse of their desire of travel to the UK. In doing so, they stylize themselves in similar ways - through their use of English, which is of course part of their post-colonial legacy, but especially through their displays of cultural references to English football, weather, geography and so on, yet knowing that, with few exceptions, the asymmetry of economic globalism does not allow them to shrug off their national identity as 'Gambians' and will not transform and transport them into the 'British'." [Jaworski and Thurlow, (2004), p.316] 
Tensions can arise because tourists expect guides to be local, granting them their authority based on their expressions of nativeness (and, thus, immobility). To avoid too much friction, guides position themselves in a transitional or liminal space that facilitates shifting between frames (Feldman, 2007). One moment they are playing the native (forced to be looking culturally inwards), and other moments they are distancing themselves from the locals (dreaming of the wide world out there).

It is clear from the above examples that various schemas of identity and identification are at work while guiding. When talking about the destination as a generalised place, the guides position themselves as locals (respecting the dominant tourism canon). However, when referring to their own person(ality), they prefer to align themselves on the side of the tourists. I argue that this position shift is mainly caused by the fact that during the guide-tourist interaction guides have to negotiate between global tourism imaginaries and their own cosmopolitan imaginations and aspirations. Having close contact with (White) tourists is considered as status enhancing in Indonesia as in Tanzania. Many guides see foreigners as their gateway into a better (Western) world. The privileged interaction with tourists nourishes their cosmopolitan dreams of escape from the harsh local life. However, as most guides realise, the most realistic chance of improving their quality of life is by becoming successful in their profession. In order to do so, they need to find the right balance in their narratives and practices between their own imaginations and the imaginaries of tourism and fantasies of tourists.

\title{
4 Discussion and conclusions
}

\begin{abstract}
"A party of elderly Americans - from their conversation I gather they are day-trippers from Malindi - is sitting at a nearby table drinking Cinzano. They are accompanied by a 'guide'... She [one of the tourists] turned toward the guide, exuding goodwill and sympathy. 'Would you like to travel abroad one day and see how other people live?' ... The guide stares wildly toward the sea. Everyone around the table is smiling relentlessly at him. 'Maybe, though, you wouldn't like it in our country. Where I come from, it's full of noise and busy people. Hurry, hurry, hurry. That's how it is in my country. You wouldn't like that, would you?' The guide, all too willing to please but not knowing precisely what is expected of him, alternately nods and shakes his head." [Naipaul, (1979), p.179]
\end{abstract}

Global tourism marketing encourages tourists to think that the very act of travel and encounter with cultural others guarantees a broadened cosmopolitan horizon - a fashionable commodity in and of itself - and greater intercultural understanding. This creates expectations that stimulate local differentiation and the resurgence of (ethnic) identities, but also leads to conflicting discourses of natural and cultural heritage. Tourism discourse often shrewdly exaggerates the power of difference while neglecting and obfuscating the power of commonality. However, as Franklin (2004, p.298) reminds us, 'it was not difference and the extraordinary that created tourism but the opposite, the extension of belonging, the prospect of taking up a place in the new national cultures that beckoned them'. Apart from erecting new or fortifying old boundaries (along lines of social class, gender, age, ethnicity, race and nationality), global tourism, thus, spreads connectivity in a world hitherto unconnected, creating a new expanding universe. In Swain's (2009, p.505) words, 'tourism is an industry built on distinctions between strangers and friends, with inherent potentials for both oppression and empowerment'. 
As local guides engage tourists in (re)constructing peoples and places, they engage in remaking themselves. Writing about guides in the highlands of Sulawesi, Adams (2006, p.61) notes:
"Although the currency of their livelihood was their knowledge of Toraja traditions, many of these young men found more compelling inspiration in global cosmopolitanism. Dedicated followers of the latest global music and media sensations, and aspiring collectors of foreign tourist 'girlfriends', these young men turned to non-religious external sources as they constructed their identities."

While the guided tour is the setting where much of the guide's cosmopolitan capital is accrued and tacitly used to better serve foreign clients, the explicit display of their cosmopolitan aspirations and lifestyle - what other scholars call 'banal cosmopolitanism' (Beck, 2002), 'vernacular cosmopolitanism' (Nava, 2002) or 'consumer cosmopolitanism' (Hannerz, 2004) - happens mainly elsewhere. They can brag to their relatives, friends and colleagues about how much they are up-to-date with trends in global popular culture and modern technology. Bringing too much of this into the encounter with Western tourists, however, would disrupt the magic of the tour. Future studies focusing on encounters between other cultures in tourism will undoubtedly refine these findings [the dynamics with Asian tourists, for example, are different (e.g., Salazar, 2008), but fall outside the scope of this article].

Guides use their privileged contact with foreigners to nourish their utopias of social mobility and to enhance their cosmopolitan status, in short, their cosmobility. However, no matter how hard they try to be cosmopolitan, tourists continue seeing them as 'local'. It looks as if local guides have to play a Janus-faced role in more than one instance. From a service-oriented point of view, they have to look simultaneously toward their foreign clients and their own (or the represented) ancestral culture and tradition. Considering their self-interests, I see guides also as liminally positioned in a temporal sense, representing the past (for tourists) while dreaming of the future (for themselves). Their liminal state is characterised by ambiguity, openness and indeterminacy, and sometimes their sense of identity dissolves to some extent, bringing about disorientation. Ironically, it is this characteristic that makes guides look modern and cosmopolitan, especially tour guides in developing countries.

Ironically, it is their cosmopolitan knowledge that helps local tour guides frame the globalised lifeworld around them as distinctively 'local'. In reality, central Java and northern Tanzania show increased signs of advanced globalisation and rapid modernisation, local guides being frontrunners of these developments. Paradoxically, the guides' dreams of moving forward and upward - becoming more cosmopolitan but also more Western - can only materialise if they represent and sell the lifeworld in which they live as developing little or not at all. In order to do so successfully, they need to constantly (mis)translate culture and (re)negotiate positions and imaginaries. Although most guides want to broaden their knowledge of the world in general, they show a particular curiosity for learning more about Western cultures. 'North-south' links are considered more attractive (because more different and more instrumental to realise their dreams). This makes their cosmopolitanism somewhat lopsided. Moreover, attention to political economy and power relations reveals that their exposure to foreign people does not necessarily imply an easy blending of cultures.

So, can or does exposure to other cultures - through people, objects, images or ideas - make people more cosmopolitan? Many of the local guides I met have developed 
a personal repertoire that provides them with multi-cultural competence and experience. They substantiate the idea that cosmopolitanism is by no means a privilege of the rich and well-connected (although, in comparison, the guides may be richer and more connected than many other people around them). Furthermore, they prove that physical or spatial mobility is not a necessary condition to become cosmopolitan. Their experiences confirm that travel signifies not only a physical movement across landscapes and cultures, but also an imaginative journey in which wonderment about those who live, think and behave differently makes it possible to see the globalised world in a different light...

\section{Acknowledgements}

This article is based on research supported by grants from the National Science Foundation (BCS-0514129 and BCS-0608991), the European Commission Directorate General Research (PIRG03-GA-2008-230892) and the Research Foundation - Flanders (1.2.210.09.N). Gadjah Mada University in Indonesia and the University of Dar es Salaam in Tanzania kindly acted as the local institutional sponsors, while the Indonesian Institute of Sciences (Permit No. 8093/SU/KS/2005) and the Tanzanian Commission for Science and Technology (Permit No. 2007-16-NA-2006-171) gave the author the necessary research clearance. The author is grateful to his research assistants, Erlis Saputra and Joseph Ole Sanguyan, for all their help. An earlier version of this article was prepared for the 1st IIPT European Conference for Peace through Tourism, October 2008.

\section{References}

Abu-Lughod, L. (1997) 'The interpretation of culture(s) after television', Representations, Summer, Vol. 59, pp.109-134.

Adams, K.M. (2006) Art as Politics: Re-crafting Identities, Tourism, and Power in Tana Toraja, Indonesia, University of Hawaii Press, Honolulu.

Appadurai, A. (1996) Modernity at Large: Cultural Dimensions of Globalization, University of Minnesota Press, Minneapolis.

Beck, U. (2002) 'The cosmopolitan society and its enemies', Theory, Culture \& Society, Vol. 19, Nos. 1/2, pp.17-44.

Beck, U. and Sznaider, N. (2006) 'A literature on cosmopolitanism: an overview', British Journal of Sociology, Vol. 57, No. 1, pp.153-164.

Bhabha, H.K. (1994) The Location of Culture, Routledge, London.

Breckenridge, C.A. et al. (Eds.) (2002) Cosmopolitanism, Duke University Press, Durham.

Brennan, T. (2001) 'The cuts of language: the east/west of north/south', Public Culture, Vol. 13, No. 1, pp.39-63.

Clifford, J. (1997) Routes: Travel and Translation in the Late Twentieth Century, Harvard University Press, Cambridge.

Dann, G.M.S. (1996) The Language of Tourism: A Sociolinguistic Perspective, CABI, Wallingford.

Favero, P. (2003) 'Phantasms in a 'starry' place: space and identification in a central New Delhi market', Cultural Anthropology, Vol. 18, No. 4, pp.551-584.

Feldman, J. (2007) 'Constructing a shared bible land: Jewish Israeli guiding performances for Protestant pilgrims’, American Ethnologist, Vol. 34, No. 2, pp.351-374. 
Franklin, A. (2004) 'Tourism as an ordering: towards a new ontology of tourism', Tourist Studies, Vol. 4, No. 3, pp.277-301.

Friedman, J. (1997) 'Global crises, the struggle for cultural identity and intellectual porkbarrelling: cosmopolitans versus locals, ethnics and nationals in an era of de-hegemonisation', in P. Werbner and T. Modood (Eds.), Debating Cultural Hybridity: Multi-Cultural Identities and the Politics of Anti-Racism, pp.70-89, Zed Books, London.

Hall, S. (1995) 'New cultures for old', in D.B. Massey and P. Jess (Eds.), A Place in the World? Places, Cultures, and Globalization, pp.175-213, Oxford University Press, New York.

Hannerz, U. (1990) 'Cosmopolitans and locals in world culture', Theory, Culture, and Society, Vol. 7, Nos. 2/3, pp.237-252.

Hannerz, U. (2004) 'Cosmopolitanism', in D. Nugent and J. Vincent (Eds.), A Companion to the Anthropology of Politics, pp.69-85, Blackwell, Oxford.

Jaworski, A. and Thurlow, C. (2004) 'Language, tourism and globalization: mapping new international identities', in S.H. Ng, C.N. Candlin and C.Y. Chiu (Eds.), Language Matters: Communication, Identity, and Culture, pp.297-321, City University of Hong Kong Press, Hong Kong.

Kahn, J.S. (2003) 'Anthropology as cosmopolitan practice?', Anthropological Theory, Vol. 3, No. 4, pp.403-415.

Kuper, A. (1994) 'Culture, identity and the project of a cosmopolitan anthropology', Man, Vol. 29, No. 3, pp.537-554.

Malcomson, S.L. (1998) 'The varieties of cosmopolitan experience', in P. Cheah and B. Robbins (Eds.), Cosmopolitics: Thinking and Feeling Beyond the Nation, pp.233-245, University of Minnesota Press, Minneapolis.

Molz, J.G. (2005) 'Getting a 'flexible eye': round-the-world travel and scales of cosmopolitan citizenship', Citizenship Studies, Vol. 9, No. 5, pp.517-531.

Naipaul, S. (1979) North of South: An African Journey, Simon \& Schuster, New York.

Narayan, K. (1993) 'How native is a 'native' anthropologist?', American Anthropologist, Vol. 95, No. 3, pp.671-686.

Nava, M. (2002) 'Cosmopolitan modernity: everyday imaginaries and the register of difference', Theory, Culture and Society, Vol. 19, Nos. 1/2, pp.81-99.

Notar, B.E. (2008) 'Producing cosmopolitanism at the borderlands: lonely planeteers and 'local' cosmopolitans in Southwest China', Anthropological Quarterly, Vol. 81, No. 3, pp.615-650.

Ong, A. (1999) Flexible Citizenship: The Cultural Logics of Transnationality, Duke University Press, Durham.

Pond, K.L. (1993) The Professional Guide: Dynamics of Tour Guiding, Van Nostrand Reinhold, New York.

Salazar, N.B. (2005) 'Tourism and glocalization: 'local' tour guiding', Annals of Tourism Research, Vol. 32, No. 3, pp.628-646.

Salazar, N.B. (2006) 'Touristifying Tanzania: global discourse, local guides', Annals of Tourism Research, Vol. 33, No. 3, pp.833-852.

Salazar, N.B. (2007) 'Towards a global culture of heritage interpretation? Evidence from Indonesia and Tanzania', Tourism Recreation Research, Vol. 32, No. 3, pp.23-30.

Salazar, N.B. (2008) 'Enough stories!' Asian tourism redefining the roles of Asian tour guides', Civilisations, Vol. 57, Nos. 1/2, pp.207-222.

Salazar, N.B. (2010) Envisioning Eden: Mobilizing Imaginaries in Tourism and Beyond, Berghahn, Oxford.

Swain, M.B. (2001) 'Cosmopolitan tourism and minority politics in the Stone Forest', in C-B. Tan, S.C.H. Cheung and H. Yang (Eds.), Tourism, Anthropology and Chinese Society, pp.125-146, White Lotus Press, Bangkok.

Swain, M.B. (2009) 'The cosmopolitan hope of tourism: critical action and worldmaking vistas', Tourism Geographies, Vol. 11, No. 4, pp.505-525. 
Tomlinson, J. (1999) Globalization and Culture, University of Chicago Press, Chicago.

Urry, J. (1995) Consuming Places, Routledge, London.

Vertovec, S. and Cohen, R. (Eds.) (2002) Conceiving Cosmopolitanism: Theory, Context and Practice, Oxford University Press, Oxford.

Werbner, P. (Ed.) (2008) Anthropology and the New Cosmopolitanism: Rooted, Feminist and Vernacular Perspectives, Berg, Oxford. 